\title{
DIVERSITY AND DISTRIBUTION OF BATS IN THE WESTERN GHATS OF INDIA
}

\author{
Vishakha Korad ${ }^{1}$, Kranti Yardi ${ }^{2}$ and Rupesh Raut ${ }^{3}$ \\ ${ }^{1}$ Department of Zoology, Fergusson College, Pune, Maharashtra 411004, India \\ ${ }^{2}$ Department of Environmental Sciences, Bharati Vidyapeeth Deemed University, Pune, Maharashtra, India \\ ${ }^{3}$ RANWA, c/o, Bhushan Patwardhan, Swastishri Society, Ganesh Nagar, Kothrud, Pune, Maharashtra 411052, India \\ Email: ${ }^{1}$ vishakhakorad@yahoo.com
}

\begin{abstract}
In this review, current patterns of distribution of bats in the Western Ghats of India are provided with endemism of species, exclusiveness in various zonesm and possible factors producing these variations. Species checklist from published literature is compiled. The number of species in six zone of $222 \mathrm{~km}$ each, their endemism at Western Ghats level and exclusiveness at zonal level is presented. Distribution patterns, habits, habitat specificity, threats and conservation measures have been included.
\end{abstract}

\section{KEYWORDS}

Bat, Chiroptera, conservation, distribution, diversity, Western Ghats

Chiroptera constitutes the second most diverse order of mammals. Studies on bats in Western Ghats are focused mainly on taxonomic identifications and species checklist in various localities in Western Ghats, but little research has been done to describe the patterns and processes involved in distribution of bat species in this region. There is a growing body of literature in community ecology describing and analyzing patterns of composition of trees, birds, butterflies, amphibians and freshwater fishes in the Western Ghats (Ghate et al., 1998; Kunte et al., 1999; Dahanukar et al., 2004). Despite the fact that India has $11.6 \%$ of world bat species, they have been neglected in these regards (Mistry, 2001). In current imperative of conserving the world's biodiversity, it is important to understand the life-scape that is patterns of distribution of biodiversity in the Western Ghats and underlying processes for changes in these patterns.

This paper focuses on current patterns of distribution of bat species across Western Ghats of India and comments on possible factors producing these variations. This study helps to understand the exclusiveness of bat fauna in various zones of Western Ghats. The conservation status of each bat species is further analyzed in these zones.

\section{Western Ghats}

Western Ghats, one of the 34 global biodiversity hotspots (Mittermeier et al., 2004) is a mountain chain running northsouth and parallel to the western coast of India. It runs rather continuously between $8^{\circ}-21^{\circ} \mathrm{N}$ latitudes, covering a distance of approximately $1600 \mathrm{~km}$ and being interrupted just once by the $30 \mathrm{~km}$ wide Palghat Gap at around $11^{\circ} \mathrm{N}$ (Fig. 1). The narrow coastal strip that separates the hill chain from the Arabian Sea in the west varies in width from $30 \mathrm{~km}$ to $60 \mathrm{~km}$; being the narrowest between $14^{\circ} \mathrm{N}$ and $15^{\circ} \mathrm{N}$. Hills are generally of elevations between $600 \mathrm{~m}$ and $1000 \mathrm{~m}$. However, there are hills with $1000 \mathrm{~m}-2000 \mathrm{~m}$ altitude between $8^{\circ} \mathrm{N}-13^{\circ} \mathrm{N}$ and $18^{\circ} \mathrm{N}-19^{\circ} \mathrm{N}$. Peaks over $2000 \mathrm{~m}$ are found only in the Nilgiris, Palanis and Anamalais. The Nilgiris and Palanis are spurs from the main hill chain, which extend the Western Ghats eastwards to approximately $78^{\circ} \mathrm{E}$ (Dahanukar et al., 2004).

Annual rainfall on the Western Ghats averages $2500 \mathrm{~mm}$ (in certain places like Agumbe, between $13^{\circ} \mathrm{N}-14^{\circ} \mathrm{N}$, rainfall exceeds $7600 \mathrm{~mm}$ ). The Western Ghats receives much of its rain from the southwest monsoon. Hence, the wettest season generally lies between June and October. The rainy season in the southern latitude is however, often prolonged locally due to premonsoon and winter showers. Thus dry periods in parts of the Western Ghats south of $13^{\circ} \mathrm{N}$ are the shortest ( 2 to 5 months), while in the north it varies from 5 to 8 months. Mean temperature ranges between $20^{\circ} \mathrm{C}-24^{\circ} \mathrm{C}$. However, it frequently shoots beyond $30^{\circ} \mathrm{C}$ during April-May (summer) and sometimes falls to $0^{\circ} \mathrm{C}$ during winter in the higher hills (Dahanukar et al., 2004).

\section{Methodology}

Species checklist from published literature was compiled. The work by Anderson (1912); Wroughton (1916); Wroughton \& Davidson (1920a,b); McCann (1934; 1940); Tate (1941); Brosset (1962a,b,c; 1963); Tiwari et al. (1971); Agrawal (1973); Bastawade \& Mahabal (1976); Hill (1976); Khajuria (1984); Das (1986); Koopman (1993); Bates et al. (1994a,b,c), Bates \& Harrison (1997); Pradhan \& Kulkarni (1997; 1999); Pradhan \& Kurup (2001); Madhavan (2000); Yardi \& Korad (2000); Nameer et al. (2001); Molur et al. (2002); Pradhan (2002); Korad \& Yardi (2001; 2002; 2004a,b); Cyriac et al. (2005); Vanitharani et al. (2003; 2004; 2005) and Vanitharani (2005 a,b) was used for compilation of species checklist. The conservation status of the bats has been adopted from Bates \& Harrison (1997); Molur et al. (2002) and Molur \& Walker (2003).

To study distribution patterns of bats the Western Ghats was divided into divisions of $2^{\circ}$ latitude (approximately $222 \mathrm{~km}$ ). The number of species in each zone, their endemism at Western Ghats level and exclusiveness at zonal level was determined by presence or absence of the species in each zone. The $8^{\circ}-12^{\circ} \mathrm{N}$ extent of Western Ghats was termed as southern region, $12^{\circ}-16^{\circ} \mathrm{N}$ as the central region and $16^{\circ}-20^{\circ} \mathrm{N}$ as the northern region. The forest classification for various zones was adopted from Ramesh \& Pascal (1997).

Bat species confined to only one of six zones were identified as exclusive. Qualitative data (presence or absence of bat species in each zone) were used to find percent similarity using Bray-Curtis similarity index (McAleece, 1998). Dendrogram was plotted to find out similarity of species in various zones.

The threat status indicated are based on the global assessments for endemics of South Asia, or national assessment

Manuscript 1563; (C) ZOO; Date of publication 21 June 2007 Received 12 May 2006; Revised received 05 June 2007; Finally accepted 09 June 2007 
for India in the case of nonendemic bats following Molur et al. (2002) and Molur \& Walker (2003).

Scientific names is after Simmons (2005).

\section{Results}

Literature records 52 species of bats from Western Ghats of which six species belong to the suborder Megachiroptera and 46 species belong to the suborder Microchiroptera (Table 1).

\section{Species diversity}

The bat fauna of Western Ghats belongs to two suborders, eight families and 25 genera (Table 1). Microchiroptera is the largest suborder contributing to $88 \%$ of bat species with seven families, of which Vespertilionidae is the most abundant family contributing $40 \%$ of the bat fauna of the Western Ghats. Family Hipposideridae (containing leaf nosed bats) is the second dominant family with $14 \%$ of total species. Of the 52 species $84 \%$ are insectivorous, $12 \%$ are frugivorous and $2 \%$ are carnivorous (Table 1 ).

\section{Habitat}

Out of 52 species recorded from Western Ghats 47\% of roost in caves, $31 \%$ roost in crevices, $8 \%$ roost in logs of dry trees and $13 \%$ roost in trees and foliage. Only one species roosts in bamboo thickets (Table 1).

\section{Colony habits}

Roosting places for 27 species (52\%) are recorded in man made structures in forests, rural or urban areas in the vicinity of forests, 17 species (31\%) are confined to forests of high altitude, mainly found in natural caves. Most of these species are reported in small groups of a few to about 25 roosting under the same shelter. Only 14 species (27\%) are gregarious in the true sense forming a colony of few hundreds to thousands (Table 1).

\section{Distribution, endemism and exclusiveness}

Table 1 suggests that 13 species are distributed all over the range of Western Ghats. Only Latidens salimalii is endemic to the Western Ghats. Western Ghats endemism is confined to zone $\mathrm{A}$, whereas exclusiveness is high in zones $\mathrm{A}, \mathrm{D}$ and $\mathrm{F}$. The dendrogram suggests that zones $\mathrm{C}, \mathrm{D}, \mathrm{E}$ and $\mathrm{F}$ have more similarity in species forming one cluster while Zones A and B are less similar to others forming the second cluster (Fig. 2).

\section{Conservation status}

As per Molur et al. (2002), 38 species are categorized as Least Concern (LC), seven as Near Threatened (NT), four as Vulnerable (VU), one as Endangered (EN), one as Critically Endangered (CR) and one as Data Deficient (DD) (Table 1) according to the 2001 IUCN Red List Criteria and Categories.

\section{Discussion}

Studies on bats in Western Ghats of India have focused mainly on taxonomic identification and listing of species in various localities.

The dendrogram (Fig. 2) shows isolation of zones A and B.
Distribution of bats seems to be governed by forest types and bioclimate of these zones. The similarity of species in remaining zones declines as the distance between two zones increases. Same trend has been reported earlier for freshwater fishes in the Western Ghats by Dahanukar et al. (2004). Zone $\mathrm{B}$ has shown maximum number of forest types (Table 2 ). This may be the reason for least similarity of this zone with other zones. Furthermore, within these forest types there are variations in bioclimates, which can cause differences in similarity of adjacent zones with same number of forest types (Table 3).

Latitudinal decline of diversity is a ubiquitous phenomenon (Hillebrand, 2004). Tropics at lower latitude harbour relatively more species per unit area than at high latitudes (Gaston, 2000). Previous studies on distribution of amphibians, angiosperms, birds, butterflies and fishes have shown that the southern region is rich in species than central and northern regions (Daniels, 1992; Kunte et al., 1996; Dahanukar et al., 2004). A similar trend can be seen in the distribution of bats of Western Ghats. Unlike endemism, southern and central regions show high exclusiveness as compared to northern region. This may be due to the fact that southern and central regions show high diversity in vegetation type (Fig. 1, Table 2), which probably creates high resource diversity.

The seasonal rain pattern suggests that dry period increases from southern to northern regions. The southern region is dry for 2 to 3 months, central region for 4 to 5 months and the northern region for 5 to 8 months (Daniels, 1992). Variation in this dry period can be one of the possible factors for distribution of bat species in southern and northern regions. Reflection of the above explanation can be seen in high exclusiveness values in southern and northern regions (Table 2).

Fifty-two species of bats included in eight families have been recorded from Western Ghats (Table 1). Most of the bat species have broad distribution, however, Kerivoula hardwickii, K. lenis, Harpiocephalus harpia, Miniopterus pussilus, M. schreibersii, Falsistrellus affinis, Pipistrellus babu, Otomops wroughtoni, Rhinolopus pusillus, Taphozous theobaldi, Rhinopoma microphyllum, Eonycterus spelaea and Latidens salimalii are restricted to only one of the six zones as defined.

The distribution of bat species can also be explained with the help of feeding guild. Frugivore bat species though represent only $12 \%$ of total species, their distribution may not be the result of mere frugivory as they show variation in their habitats and their distribution (Appendix 1). Cynopterus sphinx feeds on plants of medium height. This species is observed in urban as well as rural areas in all zones. Pteropus giganteus is reported near human dwellings but only in spur areas in the northern Western Ghats (Korad \& Yardi, 2004a). Rousettus leschenaulti prefers caves, tunnels, arches of the bridges, temples and old ruins, where water is available in the vicinity. Insectivore bat fauna is highly specialized in feeding habits. They show feeding activities at various levels from forest canopy to forest floor. Zones D, E and F show more similarity in distribution of insectivore species.

Loss of habitat and fragmentation of vegetation are two 
Table 1. Distribution and status of bats in Western Ghats

\begin{tabular}{|c|c|c|c|c|c|c|c|c|c|c|}
\hline Order/ Family/ Species\$ & $\begin{array}{l}\text { Feeding } \\
\text { Habit }\end{array}$ & Habitat & $\begin{array}{l}\text { Colony } \\
\text { habits }\end{array}$ & A & B & $\begin{array}{l}\text { Zones } \\
\text { C }\end{array}$ & D & $\mathbf{E}$ & $\mathbf{F}$ & Status \\
\hline \multicolumn{11}{|c|}{$\begin{array}{l}\text { Suborder Megachiroptera } \\
\text { Pteropodidae ( } 5 \text { genera, } 6 \text { species) }\end{array}$} \\
\hline Cynopterus brachyotis & $\mathrm{F}$ & FL & & 1 & 1 & 1 & 1 & 1 & 1 & LC \\
\hline Cynopterus sphinx & $\mathrm{F}$ & $\mathrm{T}$ & $\mathrm{CN}$ & 1 & 1 & 1 & 1 & 1 & 1 & LC \\
\hline Eonycteris spelaea & $\mathrm{F}$ & CV & & 1 & 0 & 1 & 0 & 0 & 0 & LC \\
\hline Latidens salimalii"\# & $\mathrm{F}$ & $\mathrm{CV}$ & $\mathrm{H}$ & 1 & 0 & 0 & 0 & 0 & 0 & EN \\
\hline Pteropus giganteus & $\mathrm{F}$ & $\mathrm{T}$ & $G$ & 1 & 1 & 1 & 1 & 1 & 1 & LC \\
\hline Rousettus leschenaulti & $\mathrm{F}$ & CV & $\mathrm{G}$ & 1 & 1 & 1 & 1 & 1 & 1 & LC \\
\hline \multicolumn{11}{|c|}{$\begin{array}{l}\text { Suborder Microchiroptera } \\
\text { Rhinopomatidae (1 genus, } 2 \text { species) }\end{array}$} \\
\hline Rhinopoma hardwickii & I & CV & $\mathrm{CN}$ & 1 & 0 & 0 & 1 & 0 & 0 & LC \\
\hline Rhinopoma microphyllum & 1 & CV & $\mathrm{CN}, \mathrm{H}$ & 0 & 0 & 0 & 0 & 0 & 1 & LC \\
\hline \multicolumn{11}{|c|}{ Emballonuridae (2 genera, 5 species) } \\
\hline Saccolaimus saccolaimus & I & $\pi$ & $\mathrm{CN}$ & 1 & 1 & 0 & 1 & 0 & 0 & LC \\
\hline Taphozous longimanus & i & $\mathrm{TL}$ & $\mathrm{CN}$ & 1 & 0 & 0 & 1 & 1 & 1 & LC \\
\hline Taphozous melanopogon & I & CV & $\mathrm{CN}, \mathrm{G}$ & 1 & 1 & 1 & 1 & 1 & 1 & LC \\
\hline Taphozous nudiventris & I & CV & $\mathrm{G}$ & 1 & 1 & 0 & 0 & 0 & 0 & LC \\
\hline Taphozous theobaldi & $\mathrm{I}$ & CV & $\mathrm{H}, \mathrm{G}$ & 0 & 1 & 0 & 0 & 0 & 0 & VU \\
\hline \multicolumn{11}{|c|}{ Megadermatidae (1 genus, 2 species) } \\
\hline Megaderma lyra & $\mathrm{C}$ & CV & $\mathrm{CN}, \mathrm{G}$ & 1 & 1 & 1 & 1 & 1 & 1 & LC \\
\hline Megaderma spasma & 1 & CV & $\mathrm{CN}, \mathrm{H}$ & 1 & 1 & 1 & 1 & 1 & 1 & LC \\
\hline \multicolumn{11}{|c|}{ Rhinolophidae (1 genus, 6 species) } \\
\hline Rhinolophus affinis & 1 & $\mathrm{~T}$ & $G$ & 1 & 0 & 0 & 0 & 0 & 0 & LC \\
\hline Rhinolophus beddomei & 1 & CV & $\mathrm{H}$ & 1 & 1 & 1 & 1 & 1 & 1 & NT \\
\hline Rhinolophus lepidus & i & $\mathrm{CV}$ & $\mathrm{CN}, \mathrm{H}$ & 1 & 1 & 1 & 1 & 1 & 1 & LC \\
\hline Rhinolophus luctus & I & $\mathrm{CV}, \mathrm{TL}$ & $\mathrm{CN}, \mathrm{FL}$ & 1 & 1 & 1 & 0 & 0 & 0 & NT \\
\hline Rhinolophus pusillus & I & $\mathrm{CV}$ & $\mathrm{H}$ & 1 & 0 & 0 & 0 & 0 & 0 & LC \\
\hline Rhinolophus rouxii & I & $\mathrm{CV}, \mathrm{TL}$ & $\mathrm{H}$ & 1 & 1 & 1 & 1 & 1 & 1 & NT \\
\hline \multicolumn{11}{|c|}{ Hipposideridae (1 genus, 6 species) } \\
\hline Hipposideros ater & I & CV & $\mathrm{CN}, \mathrm{H}$ & 1 & 1 & 0 & 1 & 0 & 0 & LC \\
\hline Hipposideros fulvus & I & $\mathrm{CV}$ & $\mathrm{CN}, \mathrm{G}$ & 1 & 1 & 1 & 1 & 1 & 1 & LC \\
\hline Hipposideros galeritus & I & CV & $\mathrm{CN}, \mathrm{H}$ & 0 & 0 & 1 & 0 & 1 & 0 & NT \\
\hline Hipposideros lankadiva & I & CV & $\mathrm{H}, \mathrm{G}$ & 0 & 0 & 1 & 1 & 1 & 0 & LC \\
\hline Hipposideros pomona & I & CV & $\mathrm{H}$ & 1 & 1 & 1 & 0 & 0 & 0 & LC \\
\hline Hipposideros speoris & I & CV & $\mathrm{CN}, \mathrm{G}$ & 1 & 1 & 1 & 1 & 1 & 1 & LC \\
\hline \multicolumn{11}{|c|}{ Molossidae (2 genera, 3 species) } \\
\hline Otomops wroughtoni & I & CR & & 0 & 0 & 0 & 1 & 0 & 0 & CR \\
\hline Tadarida aegyptiaca & 1 & CR & $\mathrm{CN}$ & 1 & 0 & 1 & 1 & 1 & 0 & LC \\
\hline Tadarida plicata & I & CR & $\mathrm{CN}, \mathrm{G}$ & 0 & 1 & 0 & 1 & 0 & 1 & $\mathrm{LC}$ \\
\hline \multicolumn{11}{|c|}{ Vespertilionidae (12 genera, 22 species) } \\
\hline Falsistrellus affinis & I & CR & $\mathrm{CN}$ & 0 & 1 & 0 & 0 & 0 & 0 & NT \\
\hline Harpiocephalus harpia & I & & & 1 & 1 & 0 & 0 & 0 & 0 & NT \\
\hline Hesperoptenus tickelli & 1 & $\mathrm{FL}$ & $\mathrm{H}$ & 0 & 0 & 1 & 1 & 0 & 1 & LC \\
\hline Hypsugo savii & I & CR & $\mathrm{CN}$ & 0 & 0 & 0 & 1 & 1 & 1 & VU \\
\hline Kerivoula hardwickii & 1 & CV & $\mathrm{H}$ & 0 & 0 & 1 & 0 & 0 & 0 & LC \\
\hline Kerivoula lenis & I & CR & & 1 & 0 & 0 & 0 & 0 & 0 & DD \\
\hline Kerivoula picta & I & $\mathrm{F}$ & & 1 & 0 & 1 & 1 & 1 & 1 & LC \\
\hline Miniopterus pusillus & 1 & CV & & 0 & 0 & 0 & 1 & 0 & 0 & VU \\
\hline Miniopterus schreibersii & i & $\mathrm{CV}$ & $\mathrm{H}, \mathrm{G}$ & 1 & 0 & 1 & 0 & 0 & 1 & LC \\
\hline Murina cyclotis & I & $\mathrm{FL}$ & & 1 & 0 & 0 & 0 & 0 & 0 & LC \\
\hline Myotis horsfieldii & I & $\mathrm{CR}$ & & 1 & 1 & 1 & 1 & 1 & 1 & LC \\
\hline Myotis montivagus & 1 & CR & $\mathrm{H}$ & 1 & 1 & 0 & 1 & 0 & 1 & VU \\
\hline Pipistrellus babu & I & CR & $\mathrm{CN}$ & 0 & 0 & 0 & 0 & 0 & 1 & LC \\
\hline Pipistrellus coromandra & I & CR & $\mathrm{CN}$ & 1 & 1 & 1 & 1 & 1 & 1 & LC \\
\hline Pipistrellus ceylonicus & I & CR & $\mathrm{CN}$ & 1 & 1 & 1 & 1 & 1 & 1 & LC \\
\hline Pipistrellus kuhlii & I & CR & $\mathrm{CN}$ & 0 & 0 & 0 & 1 & 1 & 1 & LC \\
\hline Pipistrellus pipistrellus & 1 & CR & $\mathrm{CN}$ & 0 & 0 & 0 & 1 & 1 & 1 & LC \\
\hline Pipistrellus tenuis & I & CR & $\mathrm{CN}$ & 0 & 1 & 1 & 1 & 1 & 1 & LC \\
\hline Scotozous dormeri & I & CR & $\mathrm{CN}$ & 1 & 0 & 1 & 1 & 1 & 1 & LC \\
\hline Scotophilus heathii & 1 & CR & $\mathrm{CN}$ & 1 & 1 & 1 & 1 & 1 & 1 & LC \\
\hline Scotophilus kuhlii & I & $\mathrm{CR}$ & $\mathrm{CN}, \mathrm{G}$ & 0 & 1 & 1 & 1 & 1 & 1 & LC \\
\hline Tylonycteris pachypus & I & B & $\mathrm{G}$ & 0 & 1 & 1 & 1 & 0 & 0 & NT \\
\hline Total $=52$ & & & & 35 & 29 & 30 & 35 & 27 & 30 & \\
\hline
\end{tabular}

Habitats: CV - Roosting in caves; T - Roosting on trees; FL - Roosting in foliage; TL - Roosting in logs of dry trees; CR - Roosting in crevices; B - Roosting in bamboo stem. Colony habits: $\mathrm{CN}$ - Roosting in man made construction; $\mathrm{H}$ - Roosting at high altitude; $\mathrm{G}$ - Gregarious species. Feeding guild:

F - Frugivorous; I - Insectivorous; C - Carnivorous. Status: LC - Least concern; EN - Endangered; VU - Vulnerable; NT - Near threatened; CR - Critically Endangered; DD - Data deficient.

\#- Species endemic to Western Ghats; \$ - Taxonomic status adopted from Bates \& Harrison (1997); Molur et al. (2002); Molur \& Walker (2003); Simmons (2005) 


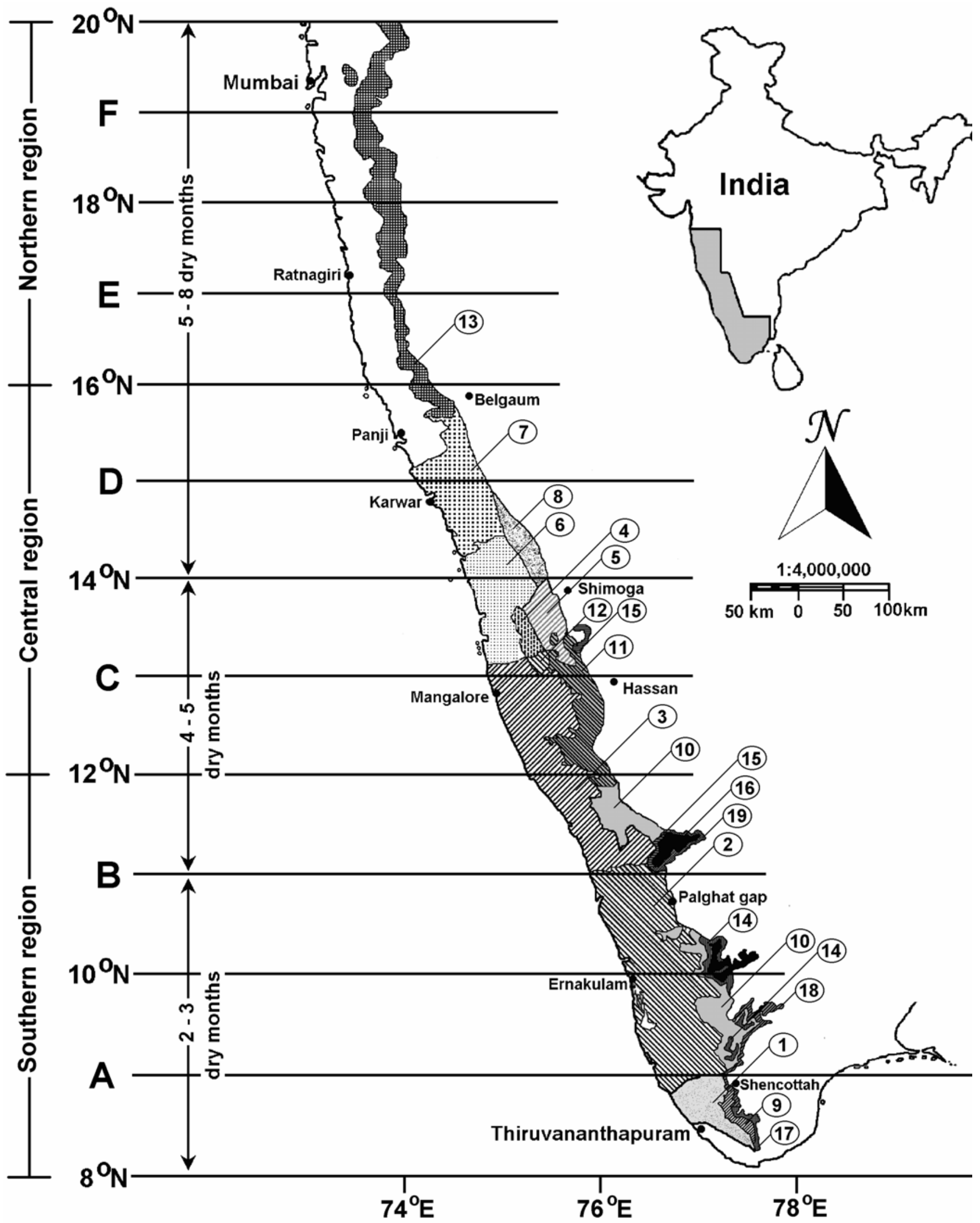

Figure 1. Major forest types and bioclimate of the Western Ghats. Map modified from Ramesh and Pascal (1997). For legends of forest types refer Table 3 
Table 2. Latitudinal distribution of bats

\begin{tabular}{|c|c|c|c|c|c|c|c|c|c|}
\hline \multirow[t]{2}{*}{ Zone } & \multirow[t]{2}{*}{ Latitude } & \multicolumn{2}{|c|}{ Families } & \multicolumn{2}{|c|}{ Genera } & \multicolumn{2}{|c|}{ Species } & \multirow{2}{*}{$\begin{array}{l}\text { Endemic } \\
\text { Species (\%) }\end{array}$} & \multirow{2}{*}{$\begin{array}{l}\text { Exclusive } \\
\text { Species (\%) }\end{array}$} \\
\hline & & $\begin{array}{l}\text { Mega- } \\
\text { chiroptera }\end{array}$ & $\begin{array}{l}\text { Michro- } \\
\text { chiroptera }\end{array}$ & $\begin{array}{l}\text { Mega- } \\
\text { chiroptera }\end{array}$ & $\begin{array}{l}\text { Michro- } \\
\text { chiroptera }\end{array}$ & $\begin{array}{l}\text { Mega- } \\
\text { chiroptera }\end{array}$ & $\begin{array}{l}\text { Michro- } \\
\text { chiroptera }\end{array}$ & & \\
\hline$A$ & 08-10 & 1 & 7 & 5 & 14 & 6 & 29 & $1(1)$ & $5(7)$ \\
\hline B & $10-12$ & 1 & 6 & 3 & 11 & 4 & 25 & 0 & $1(1)$ \\
\hline $\mathrm{C}$ & $12-14$ & 1 & 6 & 4 & 12 & 5 & 25 & 0 & 1 (1) \\
\hline D & $14-16$ & 1 & 7 & 3 & 15 & 4 & 31 & 0 & $2(4)$ \\
\hline$E$ & $16-18$ & 1 & 6 & 3 & 9 & 4 & 23 & 0 & $0(0)$ \\
\hline $\mathrm{F}$ & $18-20$ & 1 & 7 & 3 & 12 & 4 & 26 & 0 & $0(0)$ \\
\hline
\end{tabular}

Table 3. Relationship between Bioclimate ${ }^{+}$and zonal distribution of forest types

\begin{tabular}{lllllllllll}
\hline $\begin{array}{l}\text { Forest } \\
\text { type }\end{array}$ & $\begin{array}{l}\text { Rainfall } \\
(\mathrm{mm})\end{array}$ & Temp & \multicolumn{2}{l}{$\begin{array}{l}\text { Dry- } \\
\text { season }\end{array}$} & A & B & C & D & E & F \\
\hline 1 & $2000-5000$ & $>23$ & $2-3$ & + & - & - & - & - & - \\
2 & $2000-5000$ & $>20$ & $2-3$ & + & - & - & - & - & - \\
3 & $2000-6000$ & $>20$ & $4-5$ & - & + & + & - & - & - \\
4 & $5000-8000$ & $>20$ & $4.5-5.5$ & - & - & + & - & - & - \\
5 & $>2000$ & $>20$ & $5-6$ & - & - & + & - & - & - \\
6 & $3500-7000$ & $>20$ & $5-6$ & - & - & + & + & - & - \\
7 & $2000-6000$ & $>23$ & $6-7$ & - & - & - & + & - & - \\
8 & $1500-2000$ & $23-24.5$ & $6-7$ & - & - & + & + & - & - \\
9 & $2000-5000$ & $16-23$ & $2-3$ & + & - & - & - & - & - \\
10 & $2000-5000$ & $16-23$ & $2-4$ & + & + & - & - & - & - \\
11 & $2000-5000$ & $17-22$ & $4-5$ & - & - & + & + & - & - \\
12 & $5000-7000$ & $18-20$ & $4-5$ & - & - & + & - & - & - \\
13 & $5000-6500$ & $17-23$ & $5-7$ & - & - & - & + & + & + \\
14 & $3000-5000$ & $13.5-16$ & $2-3$ & - & + & - & - & - & - \\
15 & 32000 & $13.5-17$ & $3-6$ & - & + & + & - & - & - \\
16 & $900-6000$ & $<13.5$ & $0-4$ & - & + & - & - & - & - \\
17 & $1200-1500$ & $>23$ & $4-6$ & + & - & - & - & - & - \\
18 & $1200-1500$ & $>23$ & $4-5$ & + & - & - & - & - & - \\
19 & $1200-1500$ & $16-23$ & $4-6$ & + & + & - & - & - & - \\
\hline
\end{tabular}

+ - Bioclimate as mentioned by Ramesh and Pascal, 1997; \# - Forest type as mentioned in circle in Figure 1; - Temperature = Mean temperature of the coldest month

major contributors to population decline and further restrictions on distribution of bats (Nameer et al., 2001). Groups of bats, which reside in caves, crevices, tree logs, trees and foliage $(90 \%$ of total) face considerable threat due to the above mentioned activities. The worst affected among all species might be Tylonycteris pachypus and Kerivoula lenis (Bates \& Harisson, 1997; Vanitharani et al., 2003). These species require bamboo thickets for shelter and all over the Western Ghats there is heavy cutting of bamboo for commercial purpose.

From colony habits $52 \%$ of species have roosting places in urban constructions. This group faces major threats because of various man made activities. It has been reported earlier by Addline et al. (2004) that many megachiropteran and microchiropteran bats get killed during renovations of old constructions. Along with this, killing of bats for food, medicine or as pest also pose a threat to bat fauna.

Frugivorous bats are considered to be pests of orchards, but actually these bats play an important role in pollination and in turn increase fruit yield (McCann, 1940). Insectivorous bats are primary consumers of nocturnal insects and play an important role in insect control on large scale (Kunz, 1982).

Since the work on bat ecology is ongoing and much needs to be understood, Korad (2005) mentions current threats to bat fauna in the central Western Ghats of Maharashtra. There is need for more surveys exclusively for bat fauna in the entire
Figure 2. Dendrogram of the relationship among various zones drawn from similarity of bat species diversity. The similarity seems to be decreasing as the distance between zones increases

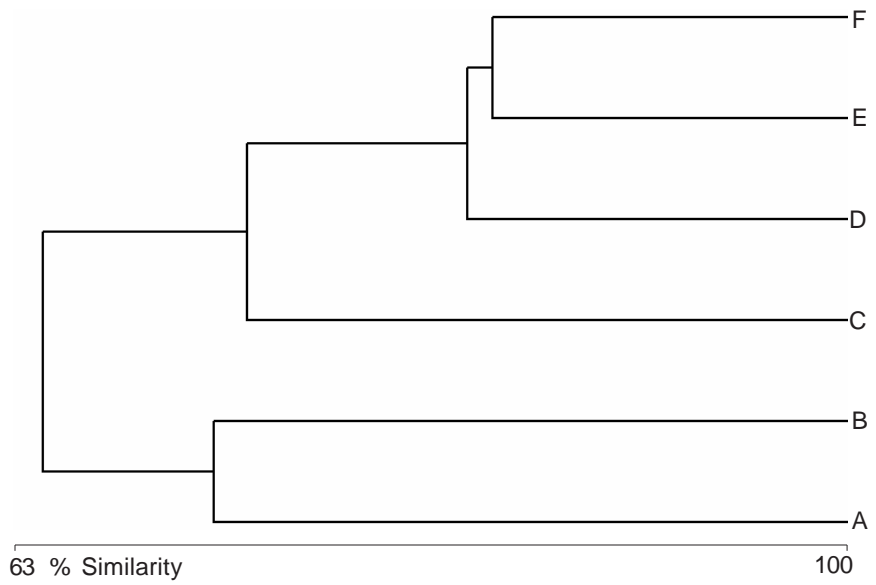

Western Ghats region for monitoring purposes, and for ecological studies of specific bat species to understand the process of forestation and the role of bats in the food web of forest ecosystem. The bat fauna has tremendous potential as bioindicator to judge the ecological stresses in the forest ecosystem. This type of study will prove vital to frame conservation measures in forest areas. The small mammal fauna in inhabiting only high altitude forests is highly specific in selecting suitable habitat. This rigidity in preference has made them vulnerable to disturbances. Most cave species of bats are experiencing ecological stresses.

Nearly $35 \%$ of the bat fauna of the Western Ghats are threatened globally or nationally. Conservation measures to protect this fauna are thus essential. The information for species occurrence in different parts of the mountain range is still incomplete due to patchy studies and inconsistent efforts and methodologies. The recent work by Juliet Vanitharani and team who recorded several bats for the first time from KalakkadMundathurai Tiger Reserve is a good eye opener for what is still unknown in the Western Ghats. Nameer et al. (2001) suggests certain conservation measures and stresses the requirement of more studies of these small mammals to understand the distribution and various effects of human intervention.

Human activities should be restricted at least in regions of remarkable bat populations. Plantation of native bamboo varieties should be encouraged to provide homes for bats as well as livelihoods for craftsmen in the area. Natural caves of 
all kinds should be systematically documented and all human activities in the caves should be banned.

\section{REFERENCES}

Addline, E.P.D., J. Vanitharani, S. Rajkumar \& R.T. Sundara (2004). Government, law and temple bat management, pp.297-301. In: Muthuchelion, K. (eds.). Biodiversity Resources Management and Sustainable Use. Centre for biodiversity and forest studies, School of energy, environment and natural resources, Madurai Kamraj University, Madurai.

Agrawal, V.C. (1973). Notes on collection of mammals from Goa. Records of the Zoological Survey of India 67: 261-280.

Anderson, K. (1912). Catalogue of The Chiroptera in The Collection of The British Museum Vol - 1: Megachiroptera. British Museum (Natural History), London.

Bastawade, D.B. \& A. Mahabal (1976). Some behavioral aspects of the Indian flying fox Pteropus giganteus giganteus. Bio-Vigyanam 2: 209-2 12.

Bates, P.J.J. \& D.L. Harrison (1997). Bats of The Indian Subcontinent. Harrison Zoological Museum Publication, England, 258pp.

Bates, P.J.J., D.L. Harrison \& M. Muni (1994a). The bats of western India, Part 1. Journal of the Bombay Natural History Society 91: 1-15.

Bates, P.J.J., D.L. Harrison \& M. Muni (1994b). The bats of western India. Part 2. Journal of the Bombay Natural History Society 91: 224-240.

Bates, P.J.J., D.L. Harrison \& M. Muni (1994c). The bats of western India, Part 3. Journal of the Bombay Natural History Society 91: 360-380.

Brosset, A. (1962a). The bats of central and western India, Part I. Journal of the Bombay Natural History Society 59: 1-57.

Brosset, A. (1962b). The bats of central and western India, Part II. Journal of the Bombay Natural History Society 59: 583-624.

Brosset, A. (1962c). The bats of central and western India, Part III. Journal of the Bombay Natural History Society 59: 707-746.

Brosset, A. (1963). The bats of central and western India, Part IV. Journal of the Bombay Natural History Society 60: 337- 355.

Cyriac, T.R., P.O. Nameer, S.R. Radhakrishnan \& R. Hari (2005). Diversity of bats in Kerala Agricultural University campus, Thrissur. Bat Net - Chiroptera Conservation and Information Network of South Asia Newsletter 6: 12-16.

Dahanukar, N., R. Raut \& A. Bhat (2004). Distribution, endemism and threat status of freshwater fishes in the Western Ghats of India. Journal of Biogeography 31: 123-136.

Daniels, R.J.R. (1992). Geographical distribution patterns of amphibians in the Western Ghats, India. Journal of Biogeography 19: 521-529.

Das, P.K. (1986). Studies on the taxonomic and geographical distribution of the species of bats obtained by the Silent Valley (Kerala, India) Expedition, 1980. Records of the Zoological Survey of India 84(1-4): 259-276.

Gaston, K.J. (2000). Global patterns in biodiversity. Nature 405: 220-227. Ghate, U., N.V. Joshi \& M. Gadgil (1998). On the patterns of tree diversity in the Western Ghats of India. Current Science 75: 594-603.

Hill, J.E. (1976). Further records of Myotis peshwa (Thomas, 1915) (Chiroptera: Vespertilionidae) from the Indian peninsula. Journal of the Bombay Natural History Society 73: 433-437.

Hillebrand, H. (2004). On the generality of the latitudinal diversity gradient. The American Naturalist 163: 192-211.

Khajuria, H. (1984). Notes on some central Indian bats. Journal of Zoological Society India 36: 125-126.

Koopman, K. (1993). Chiroptera, pp.137-241. In: Wilson, D.E. \& D.M. Reeder (eds). Mammal Species of The World. Smithsonian Institution Press, Washington DC, USA, xvii+1207pp.

Korad, V.S. (2005). Assessment of Bat Fauna in The Central Western Ghats of Maharashtra (2002-2005). A report submitted to the ministry of Environment and forests.

Korad, V.S. \& K.D. Yardi (2001). Notes on free tailed bats from Pune city Bat Net - Chiroptera Conservation and Information Network of South Asia Newsletter 2: 11-12.

Korad, V.S. \& K.D. Yardi (2002). True conservators of bats. Bat NetChiroptera Conservation and Information Network of South Asia Newsletter 3: 15-16.

Korad, V.S. \& K.D. Yardi (2004a). Ecological study and faunastic survey of bats from Pune corporation limits, Maharashtra State, India. Records of Zoological Survey of India 102: 115-136.
Korad, V.S. \& K.D. Yardi (2004b). New records of some bats from central western India. Records of Zoological Survey of India 103: 171-177.

Kunte, K., A. Joglekar, U. Ghate \& P. Padmanabhan (1999). Patterns of butterfly, bird and tree diversity in the Western Ghats. Current Science 77: 577-586.

Kunz, T.H. (1982). Roosting ecology of bats. In: Kunz, T.H. (ed.) Ecology of Bats. Plenum Press, New York, 425pp.

Madhavan, A. (2000). A catalogue of bats recorded in Thrissur district, Kerala. Zoos' Print Journal 15: 355-358.

McAleece, N. (1998). Biodiversity Professional Beta. The Natural History Museum and Scottish Association for Marine Sciences.

McCann, C. (1934). Further observation on the flying fox (Pteropus giganteus Brunn) and the fulvous fruit-bat (Rousettus leschenaulti Desm.). Journal of the Bombay Natural History Society 42: 587-592.

McCann, C. (1940). The short nosed fruit bat (Cynopterus sphinx) as an agent of seed dispersal in the wild date (Phoenix sylvestris). Journal of the Bombay Natural History Society 42: 184-185.

Mistry, S. (2001). Biogeographhic patterns of Indian bats: Identifying hot-spots for conservation. In: Ganeshaiah, K.N., R.U. Shaankar \& K.S. Bawa (eds.). Tropical Ecosystems: Structure, Diversity and Human Welfare. Proceedings of the International conference on tropical ecosystems. Oxford-IBH publications, $791 \mathrm{pp}$.

Mittermeier, R.A., P.R. Gil, M. Hoffmann, J. Pilgrim, T. Brooks, C.G. Mittermeier, J. Lamoreux \& G.A.B. Da Fonseca (2004). Hotspots Revisited.: Earth's Biologically Richest and Most Endangered Terrestrial Ecoregions. CEMEX, 390pp.

Molur, S. \& S. Walker (2003). Endemic bats of South Asia IUCN Red List and justification for status assessment. Bat Net - Chiroptera Conservation and Information Network of South Asia Newsletter 4: 9-12.

Molur, S., G. Marimuthu, C. Srinivasulu, S. Mistry, A.M. Hutson, P.J.J. Bates, S. Walker, K. Padma Priya \& A.R. Binu Priya (eds.) (2002). Status of South Asian Chiroptera: Conservation Assessment and Management Plan (C.A.M.P) Workshop Report, 2002. Zoo Outreach Organisation, CBSG South Asia and WILD, Coimbatore, India, viii+141pp+CD-ROM.

Myers, N., R.A. Mittermeier, C.G. Mittermeier, G.A.B. da Fonesca, \& J. Kent (2000). Biodiversity hotspots for conservation priorities. Nature 403: 853-858.

Nameer, P.O., S. Molur \& S. Walker (2001). Mammals of Western Ghats: A simplistic overview. Zoos' Print Journal 16: 629-639.

Pradhan, M.S. (2002). Mammalia, pp.79-97. In: Director Zoological Survey of India, Kolkata (ed.). Fauna of Eravikulum National Park. Fauna of Conservation Area Series, 13.

Pradhan, M.S. \& G.U. Kurup (2001). Mammalia, pp.311-330. In: Director Zoological Survey of India, Kolkata (ed.). Fauna of Nilgiri Biosphere Reserve. Fauna of Conservation Area Series, 11

Pradhan, M.S. \& P.P. Kulkarni (1997). Observations on the extended distribution of Cynopterus brachyotis ceylonensis Gray in Western India with comments on its status. Mammalia 61(1): 116-118.

Pradhan, M.S. \& P.P. Kulkarni (1999). Cynopterus brachyotis in other localities in the Western Ghats. Current Science 77(10): 1228- 1229

Ramesh, B.R. \& J.P. Pascal (1997). Atlas of endemics of the Western Ghats (India). Distribution of tree species in the evergreen and semi-evergreen forests. Institut français de Pondichéry, Publications du départment d'écologie, $n^{\circ}$ 38.

Simmons, N.B. (2005). Order: Chiroptera, pp.312-529. In: Wilson, D.E. \& D.M. Reeder (eds). Mammal Species of the World: A Taxonomic and Geographic Reference, Volume 1. $3^{\text {rd }}$ edition. Johns Hopkins University Press, Baltimore, $\mathrm{xxxv}+743 \mathrm{pp}$.

Tate, G.H.H. (1941). Notes on oriental Taphozous and allies. American Museum novitates no. 1141 .

Tiwari, K.K., R.K. Ghose \& S. Chakraborty (1971). Notes on collection of small mammals from Western Ghats, with remarks on the status of Rattus rufescens (Gray) and Bandicota indiaca malbarica (Shaw). Journal of the Bombay Natural History Society 68: 378-384.

Vanitharani, J. (2005a). Noteworthy representatives of bat species in Agasthiyamalai biosphere reserve, Tamil Nadu, India. Journal of theoretical and experimental biology 2(2): 47-59.

Vanitharani, J. (2005b). Special report about Latidens salimalii of Kalakad 
Mundanthurai Tiger Reserve. Bat Net - Chiroptera Conservation and Information Network of South Asia Newsletter 6: 7-9.

Vanitharani, J., A. Rajendra, P.J.J. Bates, D. Harrison \& M. Pearch (2003). A taxonomic reassessment of Kerivoula lenis Thomas, 1916 (Chiroptera: Vespertilionidae) including a first record from peninsular India. Acta Chiropterologica 5(1): 49-60.

Vanitharani, J., M. Pearch, L.J. Praba \& R. Annamalai (2004). A review of the distribution and status of Latidens salimali (Chiroptera: Pteropodidae) with new records from the Western Ghats, India. Lutra 47(1): 21-32.

Vanitharani, J., U.S.U. Malathi \& K.A. Sundari (2005). New records of bats from Kalakad Mundanthurai Tiger Reserve. Bat Net - Chiroptera Conservation and Information Network of South Asia Newsletter 6: 13-14.

Wroughton, R.C. (1916). [iii] Report No. 22: Koyna Valley [311-316]. Bombay Natural History Society's Mammal Survey of India, Burma and Ceylon. Journal of the Bombay Natural History Society 24: 291- 316. Wroughton, R.C. \& W.M. Davidson (1920a). Report No. 30: Dekhan, Poona District. Journal of the Bombay Natural History Society 26: 1025- 1035. Wroughton, R.C. \& W.M. Davidson (1920b). Report No. 31: Nilgiris. Journal of the Bombay Natural History Society 26: 1031-1035.

Yardi, K.D. \& V.S. Korad (2000). Bat fauna of Pune city. Journal of Ecological Society 13/14: 71-73

\section{ACKNOWLEDGEMENTS}

We thank Principal, Fergusson College, Pune and Head, Department of Zoology, Fergusson College, Pune for providing necessary facilities. We are thankful to M.S. Pradhan \& Anil Mahabal, Zoological Survey of India, Western Region Office, Pune for valuable suggestions, assistance in taxonomical work and moral support. Thanks are due to the authorities of the Bombay Natural History Society for providing library facilities. We also thank Mahesh Gaikwad, Abhijeet Koratkar and Uttam Chavan for their help in field studies. We thank Neelesh Dahanukar for comments on manuscript and graphical work. Mandar Paingankar gave valuable suggestions on the manuscript.

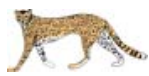

\section{WANTED: CONSERVATION OUTREACH PROJECT CO-ORDINATOR Centre for Wildlife Studies, Bangalore}

We are looking for Conservation Outreach Co-ordinator of wildlife conservation issues is essential. Good skills in administration, correspondence and computers are required. Should be literate in Kannada as well as English, and must possess good social/communication skills. Knowledge of photoshop and web maintenance would be an added advantage, but not essential. Excellent remuneration for the right candidate.

If you know of anyone who is interested to apply please ask them to contact the following address with $\mathrm{CV}$ immediately. Thanks in advance for circulating this to your friends/colleagues/department.

Mr. K.V. Phaniraj, Manager (Finance \& Adminstration), Centre for Wildlife Studies, $823,13^{\text {th }}$ Cross, $7^{\text {th }}$ Block West, Jayanagara, Bengaluru - 560082

Phone: +91080 26715364

Email: admin@wcsindia.org in the 20-35 years age-range. Interest/knowledge

\section{INCLUSIVE PLANNING AND ALLOCATION FOR FOREST CONSERVATION THROUGH RURAL SERVICES: AN EXPERIENCE}

\section{Aeshita Mukherjee}

Gujarat Institute of Development Research, Ahmedabad, Gujarat 380060, India

Present address: Xishungbanna Tropical Botanical Garden, Chinese Academy of Sciences, Mengla, Menglun 666303, P.R. China Email: aesh2003@yahoo.com, aesh@xtbg.org.cn

The Gir National Park and Sanctuary is one amongst the seven protected areas selected for biodiversity conservation through Eco-Development Project funded by World Bank. One of the major steps taken was restricting the inhabitants of this forest to enter the National Park and thus rehabilitating them to the fringes of the protected areas. This has also enacted a restriction in using the forest resources and thus has created an unsaid conflict between the forest and its dwellers. Over the years however, it has been realized that for effective management of the protected area is not possible without addressing the legitimate needs of the locals.

To protect the natural resource, eco development project was a commitment in transforming the way services are planned and financed; a new association between the local governments, NGOs and private sector agencies are being created. Much attention has focused on adoption of various techniques with special emphasis on people's participation, through which direct and intensive involvement of locals can be encouraged in decentralized planning. This trend was critically examined and potential unintended consequences are highlighted. A broader concept of accountability is outlined to illustrate a more inclusive approach to planning and allocation for more equity and sustainability in rural services.

Sloganeering about 'participation in development', which has now become mandatory to attract and passing policies, however, no longer goes without challenge. Tallying up the once-hidden vices of participation alongside its known virtues, a recent review concluded that participatory development is an 'essentially contested concept' (Cernea, 1985). Yet it is clear that delivery of sustainable, equitable and affordable rural services is helped if service users are involved in choices about priorities and delivery options. They tend to be more prepared to invest their own resources and sometimes, though not as often as hoped, this involvement makes those services more accessible to vulnerable sections of the population (Cernea, 1985).

In developing countries, it is often argued that this kind of participation is constrained by the representative political process. The political, economic and social, connections between elected leaders and their constituency is simply too great for voices to be heard and participation to be effective. Thus special measures are welcomed. In response it has been agreed that intensive community consultation techniques (such as found in the 'PRA toolbox' much popularised by Robert Chambers and associates) can greatly improve the quality of local service planning decisions. Most donors now insist that these techniques are adopted and Manuscript 1423; @ ZOO; Date of publication 21 June 2007 Received 25 August 2005; Finally accepted 30 August 2006 July 2007 | ISSN 0973-2535 (Print edition); 0973-2551 (Online edition) www.zoosprint.org 